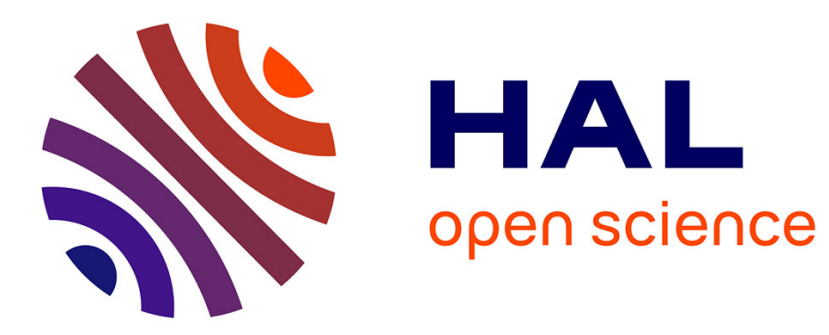

\title{
Effect of Annealing on Structural and Thermodynamic Properties of ThSiO4-ErPO4 Xenotime Solid Solution
}

\author{
A. Shelyug, M. Rafiuddin, Adel Mesbah, Nicolas Clavier, Stephanie \\ Szenknect, Nicolas Dacheux, X. Guo, A. Navrotsky
}

\section{To cite this version:}

A. Shelyug, M. Rafiuddin, Adel Mesbah, Nicolas Clavier, Stephanie Szenknect, et al.. Effect of Annealing on Structural and Thermodynamic Properties of ThSiO4-ErPO4 Xenotime Solid Solution. Inorganic Chemistry, 2021, 60 (16), pp.12020-12028. 10.1021/acs.inorgchem.1c01137 . hal-03343982

\author{
HAL Id: hal-03343982 \\ https://hal.science/hal-03343982
}

Submitted on 19 Oct 2021

HAL is a multi-disciplinary open access archive for the deposit and dissemination of scientific research documents, whether they are published or not. The documents may come from teaching and research institutions in France or abroad, or from public or private research centers.
L'archive ouverte pluridisciplinaire $\mathbf{H A L}$, est destinée au dépôt et à la diffusion de documents scientifiques de niveau recherche, publiés ou non, émanant des établissements d'enseignement et de recherche français ou étrangers, des laboratoires publics ou privés. 


\title{
Effect of annealing on structural and thermodynamic properties of $\mathrm{ThSiO}_{4}-\mathrm{ErPO}_{4}$ xenotime solid solution
}

Anna Shelyug ${ }^{1}$, Mohamed Ruwaid Rafiuddin ${ }^{2}$, Adel Mesbah ${ }^{2,3}$, Nicolas Clavier ${ }^{2}$, Stéphanie Szenknect ${ }^{2}$, Nicolas Dacheux ${ }^{2}$, Xiaofeng Guo ${ }^{4}$, Alexandra Navrotsky ${ }^{5 *}$

${ }^{1}$ Institute of Solid State Chemistry, Yekaterinburg 620990, Russia

${ }^{2}$ ICSM, Univ Montpellier, CNRS, CEA, ENSCM, Site de Marcoule, Bagnols-sur-Cèze, France

${ }^{3}$ Univ Lyon, Université Lyon 1, Institut de Recherches sur la Catalyse et l'Environnement de Lyon, IRCELYON, UMR5256, CNRS, 2 Avenue Albert Einstein, 69626, Villeurbanne Cedex, France

${ }^{4}$ Department of Chemistry and Alexandra Navrotsky Institute for Experimental Thermodynamics, Washington State University, Pullman, WA 99164, USA

${ }^{5}$ School of Molecular Sciences a Center for Materials of the Universe, Arizona State University, Tempe, AZ 85287, USA

*Corresponding author: Alexandra Navrotsky alexandra.navrotsky@asu.edu

\begin{abstract}
The effect of annealing on structural and thermochemical properties of the thorite-xenotime solid solution $\mathrm{Th}_{1-x} \mathrm{Er}_{x}\left(\mathrm{SiO}_{4}\right)_{1-x}\left(\mathrm{PO}_{4}\right)_{x}$ was assessed. The samples synthesized at low temperatures and stored at room temperature for two years retained their tetragonal structure. This structure was also maintained after heating to $1100^{\circ} \mathrm{C}$. During annealing, the structure lost water and exsolved some thorianite phase. The thermodynamic parameters did not change much after annealing, suggesting that xenotime was not a low temperature metastable phase but rather a stable structure able to withstand elevated temperatures regardless of thorium content. The solid solution exhibited subregular behavior with the Margules function $W(x)=(73.1 \pm 20.1)-(125.7 \pm 49.8) \cdot x$.
\end{abstract}

\section{INTRODUCTION}

Monazite $\left(\mathrm{REPO}_{4} ; \mathrm{RE}=\mathrm{La}\right.$ to $\left.\mathrm{Gd}\right)$, xenotime $\left(\mathrm{REPO}_{4} ; \mathrm{RE}=\mathrm{Tb}\right.$ to $\mathrm{Lu}$ and $\left.\mathrm{Y}\right)$, and zircon $\left(\mathrm{MSiO}_{4} ; \mathrm{M}\right.$ $=\mathrm{Zr}, \mathrm{Hf}, \mathrm{Th}, \mathrm{U})$ are widespread naturally occurring minerals ${ }^{1-6}$ found in granitic and metamorphic rocks. ${ }^{7-11}$ These minerals offer great compositional flexibility and can accommodate a wide range of combinations of rare earth elements $(\mathrm{RE})$, natural actinides ( $\mathrm{AN}=\mathrm{U}$ and $\mathrm{Th}$ ), and several anionic species within their crystal structure. For the geochemical community, owing to the presence of actinides $(\mathrm{U}, \mathrm{Th})$, associated daughter elements $(\mathrm{Pb})$ and their high chemical durability, these minerals are often used for geochronology applications (dating methods). ${ }^{12-20}$ The ability of these minerals to host various types of cations draws interest for nuclear waste management. ${ }^{1,21-27}$ As a result, these materials have been proposed as a ceramic waste form for the disposal of minor actinides or plutonium resulting from dismantled nuclear weapons and reprocessing of spent nuclear fuel. ${ }^{28,29}$ Both, $\mathrm{REPO}_{4}$ and $\mathrm{MSiO}_{4}$ matrices have shown promising properties such as high resistance to aqueous alteration and radiation damage..$^{2,26,29-32}$ 
In rare-earth phosphates $\left(\mathrm{REPO}_{4}\right)$, the incorporation of tetravalent uranium and thorium into the structure occurs mainly through two different substitution mechanisms. The one most reported is the coupled cationic substitution:

$$
2 \mathrm{RE}^{3+} \leftrightarrow \mathrm{Ca}^{2+}+\mathrm{AN}^{4+}
$$

Such substitution was first reported in minerals by Förster ${ }^{6}$ and then confirmed in different synthetic compounds. ${ }^{25,33,34}$ The second mode of incorporation of tetravalent elements into the phosphate minerals is through the formation of solid solution between $\mathrm{REPO}_{4}$ and $\mathrm{ANSiO}_{4}$ compounds. This occurs through simultaneous substitution in the cationic and anionic sites:

$$
\mathrm{RE}^{3+}+\mathrm{PO}_{4}{ }^{3-} \leftrightarrow(\mathrm{Th}, \mathrm{U})^{4+}+\mathrm{SiO}_{4}{ }^{4-}
$$

These substitutions were reported to exist in natural mineral phases. ${ }^{35}$ One of the first examples of synthetic Th- and U-containing phosphosilicates was reported by McCarthy et al. ${ }^{36}$ In that study, phase-pure $\mathrm{RE}_{0.7} \mathrm{Th}_{0.27} \mathrm{U}_{0.03}\left(\mathrm{PO}_{4}\right)_{0.7}\left(\mathrm{SiO}_{4}\right)_{0.3}(\mathrm{RE}=\mathrm{Gd}, \mathrm{Nd}, \mathrm{Ce}, \mathrm{La}, \mathrm{Pr}, \mathrm{Sm}, \mathrm{Y})$ samples were synthesized using a coprecipitation method. Mesbah et al. synthesized $\operatorname{Th}_{\mathrm{x}} \mathrm{Er}_{1-\mathrm{x}}\left(\mathrm{SiO}_{4}\right)_{\mathrm{x}}\left(\mathrm{PO}_{4}\right)_{1-\mathrm{x}}$ samples in the entire compositional range by a hydrothermal method. ${ }^{37}$ Thermodynamic behavior of this system was not assessed then, despite its importance to nuclear waste applications and hence, in this study we continue to investigate the $\mathrm{Th}_{\mathrm{x}} \mathrm{Er}_{1-\mathrm{x}}\left(\mathrm{SiO}_{4}\right)_{\mathrm{x}}\left(\mathrm{PO}_{4}\right)_{1-\mathrm{x}}$ solid solution from a thermochemical perspective. We also review the structural properties of this system after prolonged storage and heating.

\section{MATERIALS AND METHODS}

\section{Synthesis}

The $\mathrm{Th}_{\mathrm{x}} \mathrm{Er}_{1-\mathrm{x}}\left(\mathrm{SiO}_{4}\right)_{\mathrm{x}}\left(\mathrm{PO}_{4}\right)_{1-\mathrm{x}}$ solid solution series in the entire compositional range $(0 \leq \mathrm{x} \leq 1)$ were synthesized hydrothermally. ${ }^{37} \mathrm{Th}\left(\mathrm{NO}_{3}\right)_{4} \cdot 4-5 \mathrm{H}_{2} \mathrm{O}, \mathrm{ErCl}_{3} \cdot \mathrm{nH}_{2} \mathrm{O}, \mathrm{NaOH}, \mathrm{NaHCO}_{3}, \mathrm{Na}_{2} \mathrm{SiO}_{3}, \mathrm{H}_{3} \mathrm{PO}_{4}$ (all analytical grade supplied by Sigma-Aldrich) were the reactants. For each composition, aqueous solutions containing $\mathrm{Er}$ and $\mathrm{Th}$ were added dropwise to an anionic solution containing precise amounts of $\mathrm{Na}_{2} \mathrm{SiO}_{3}$ and $\mathrm{H}_{3} \mathrm{PO}_{4}$. Then the $\mathrm{pH}$ of the solution was raised to 11.3 using $\mathrm{NaOH}(8 \mathrm{M})$, and finally adjusted to 8.7 by $\mathrm{NaHCO}_{3}$ buffer. The final mixture was transferred into a teflon-lined acid digestion bomb (Parr) and held for 7 days at $250{ }^{\circ} \mathrm{C}$. The final product was washed twice with water and once with ethanol. The samples were thus stored in airtight containers for 2 years prior to thermodynamic analysis. Appropriate care was taken for handling thorium, which is a long-life $\alpha$ emitter. The list of samples with their compositions measured by EDX is given in Table 1. One sample with composition $\mathrm{Th}_{0.2} \mathrm{Er}_{0.8}\left(\mathrm{SiO}_{4}\right)_{0.2}\left(\mathrm{PO}_{4}\right)_{0.8}$ was synthesized separately following the same procedure for the in situ PXRD analysis, but the time before the experiment was less than a month.

Table 1. Composition of the $\operatorname{Th}_{\mathrm{x}} \mathrm{Er}_{1-\mathrm{x}}\left(\mathrm{SiO}_{4}\right)_{\mathrm{x}}\left(\mathrm{PO}_{4}\right)_{1-\mathrm{x}}$ samples as reported in ${ }^{37}$.

\begin{tabular}{ccccccc}
\hline Sample name $^{\#}$ & $\mathbf{x}$ & $\mathbf{T h}$ & $\mathbf{E r}$ & $\mathbf{S i}$ & $\mathbf{P}$ & Actual composition of xenotime \\
\hline 10Th & 0.1 & 0.11 & 0.89 & 0.14 & 0.86 & $\mathrm{Th}_{0.11} \mathrm{Er}_{0.89}\left(\mathrm{SiO}_{4}\right)_{0.11}\left(\mathrm{PO}_{4}\right)_{0.89}$ \\
20Th & 0.2 & 0.19 & 0.81 & 0.26 & 0.74 & $\mathrm{Th}_{0.19} \mathrm{Er}_{0.81}\left(\mathrm{SiO}_{4}\right)_{0.19}\left(\mathrm{PO}_{4}\right)_{0.81}$ \\
30Th & 0.3 & 0.25 & 0.75 & 0.30 & 0.70 & $\mathrm{Th}_{0.25} \mathrm{Er}_{0.75}\left(\mathrm{SiO}_{4}\right)_{0.25}\left(\mathrm{PO}_{4}\right)_{0.75}$ \\
40Th & 0.4 & 0.43 & 0.57 & 0.47 & 0.53 & $\mathrm{Th}_{0.43} \mathrm{Er}_{0.57}\left(\mathrm{SiO}_{4}\right)_{0.43}\left(\mathrm{PO}_{4}\right)_{0.57}$ \\
50Th & 0.5 & 0.44 & 0.56 & 0.55 & 0.45 & $\mathrm{Th}_{0.44} \mathrm{Er}_{0.56}\left(\mathrm{SiO}_{4}\right)_{0.44}\left(\mathrm{PO}_{4}\right)_{0.56}$ \\
60Th & 0.6 & 0.56 & 0.44 & 0.65 & 0.35 & $\mathrm{Th}_{0.56} \mathrm{Er}_{0.44}\left(\mathrm{SiO}_{4}\right)_{0.56}\left(\mathrm{PO}_{4}\right)_{0.44}$
\end{tabular}




$\begin{array}{lllllll}70 \mathrm{Th} & 0.7 & 0.64 & 0.36 & 0.73 & 0.27 & \mathrm{Th}_{0.64} \mathrm{Er}_{0.36}\left(\mathrm{SiO}_{4}\right)_{0.64}\left(\mathrm{PO}_{4}\right)_{0.36} \\ \text { 80Th } & 0.8 & 0.76 & 0.24 & 0.84 & 0.16 & \mathrm{Th}_{0.76} \mathrm{Er}_{0.24}\left(\mathrm{SiO}_{4}\right)_{0.76}\left(\mathrm{PO}_{4}\right)_{0.24} \\ \text { 90Th } & 0.9 & 0.88 & 0.12 & 0.95 & 0.05 & \mathrm{Th}_{0.88} \mathrm{Er}_{0.11}\left(\mathrm{SiO}_{4}\right)_{0.88}\left(\mathrm{PO}_{4}\right)_{0.11}\end{array}$

"The numbers of "xTh" represent the approximate mole fraction of Th in the sample

\section{Powder X-Ray Diffraction (PXRD)}

Powder X-ray diffraction (PXRD) was performed on a Bruker AXS-D8 Advance diffractometer (Bruker-AXS, Inc., Billerica, MA) operated at $40 \mathrm{kV}$ accelerating voltage with $40 \mathrm{~mA}$ emission current using a copper $\mathrm{X}$-ray target for the initial phase check and to find lattice constants of the final samples. The data were collected from 20 to $80^{\circ} 2 \theta$ using a step size of $0.012^{\circ} 2 \theta$. The PXRD patterns were further analyzed for the determination of lattice parameters by a whole profile fitting procedure (Jade v6.11, 2002, Materials Data Inc., Livermore, CA).

The in situ PXRD experiments were conducted on a separately synthesized $\mathrm{Th}_{0.2} \mathrm{Er}_{0.8}\left(\mathrm{SiO}_{4}\right)_{0.2}\left(\mathrm{PO}_{4}\right)_{0.8}$ using a Bruker Model D8 X-ray diffractometer equipped with a curved Ge-monochromator (111), a $\mathrm{Cu}$ X-ray source $(40 \mathrm{kV}, 40 \mathrm{~mA})$, a Lynx Eye position-sensitive detector, and Anton Paar HTK 2000 chamber. The data were collected from $2 \theta=5$ to $100^{\circ}$ using a step size of $0.012^{\circ} 2 \theta$. Patterns were collected at $100{ }^{\circ} \mathrm{C}$ intervals to $1100{ }^{\circ} \mathrm{C}$. They were further analyzed by the Rietveld method with General Structure Analysis System (GSAS) software version II. ${ }^{38}$ The instrument parameters were obtained using a $\mathrm{LaB}_{6}$ standard, the background was modelled with a Chebyshev function (8 terms), and the peak profiles were fitted with pseudo-Voigt convolution functions. ${ }^{39}$ Detailed procedures to analyze the XRD data were described previously elsewhere. ${ }^{40,41}$

\section{Calorimetry and Thermal Analysis}

High temperature oxide melt solution calorimetry was performed using a custom-built Tian-Calvet twin calorimeter. Approximately $5 \mathrm{mg}$ of sample was hand-pressed into a pellet to drop from room temperature into $20 \mathrm{~g}$ of molten lead borate $\left(2 \mathrm{PbO}-\mathrm{B}_{2} \mathrm{O}_{3}\right.$ at $\left.800{ }^{\circ} \mathrm{C}\right)$. Oxygen was bubbled $(5 \mathrm{~mL} / \mathrm{min})$ through the solvent and flushed $(70 \mathrm{~mL} / \mathrm{min})$ through the gas space above it to enhance dissolution and maintain an oxidizing atmosphere. The heat effect was evaluated using Calisto software by integrating the thermopile signal over time. The methodology adopted in this study was identical to that in prior studies on similar systems. ${ }^{31,42-44}$

Simultaneous TGA-DSC analyses were performed with a Netzsch STA 449 C instrument coupled with a Micromeritics Cirrus 2 quadrupole mass spectrometer. The samples were annealed in a Pt pan in air from room temperature up to $1000{ }^{\circ} \mathrm{C}$ with a heating rate of $10{ }^{\circ} \mathrm{C} / \mathrm{min}$. The change in the mass of the sample was monitored and the gases evolved during the heating process were introduced into the ionization chamber of mass spectrometer. The signals were corrected by the reference baselines from runs with empty crucibles under the same experimental conditions. After TGA-DSC experiments, the samples were recovered for additional characterization.

\section{Infrared Spectroscopy}

Attenuated total reflectance-Fourier transform infrared (ATR-FTIR) spectra of all the samples were recorded using a Bruker Model Alpha-P IR spectrometer (diamond ATR cell, $4 \mathrm{~cm}^{-1}$ resolution, 400$\left.4000 \mathrm{~cm}^{-1}\right)$.

\section{RESULTS AND DISCUSSION}




\section{TGA-DSC-MS}

TGA-DSC scans and corresponding MS signals for the samples 20Th and 80Th are shown in Figure $\boldsymbol{1}$ (see Figure $\mathbf{1 S}$ in supplementary information for the rest of the scans). While MS was performed without any calibration and remained qualitative rather than quantitative, we could identify which gases evolved during heating.

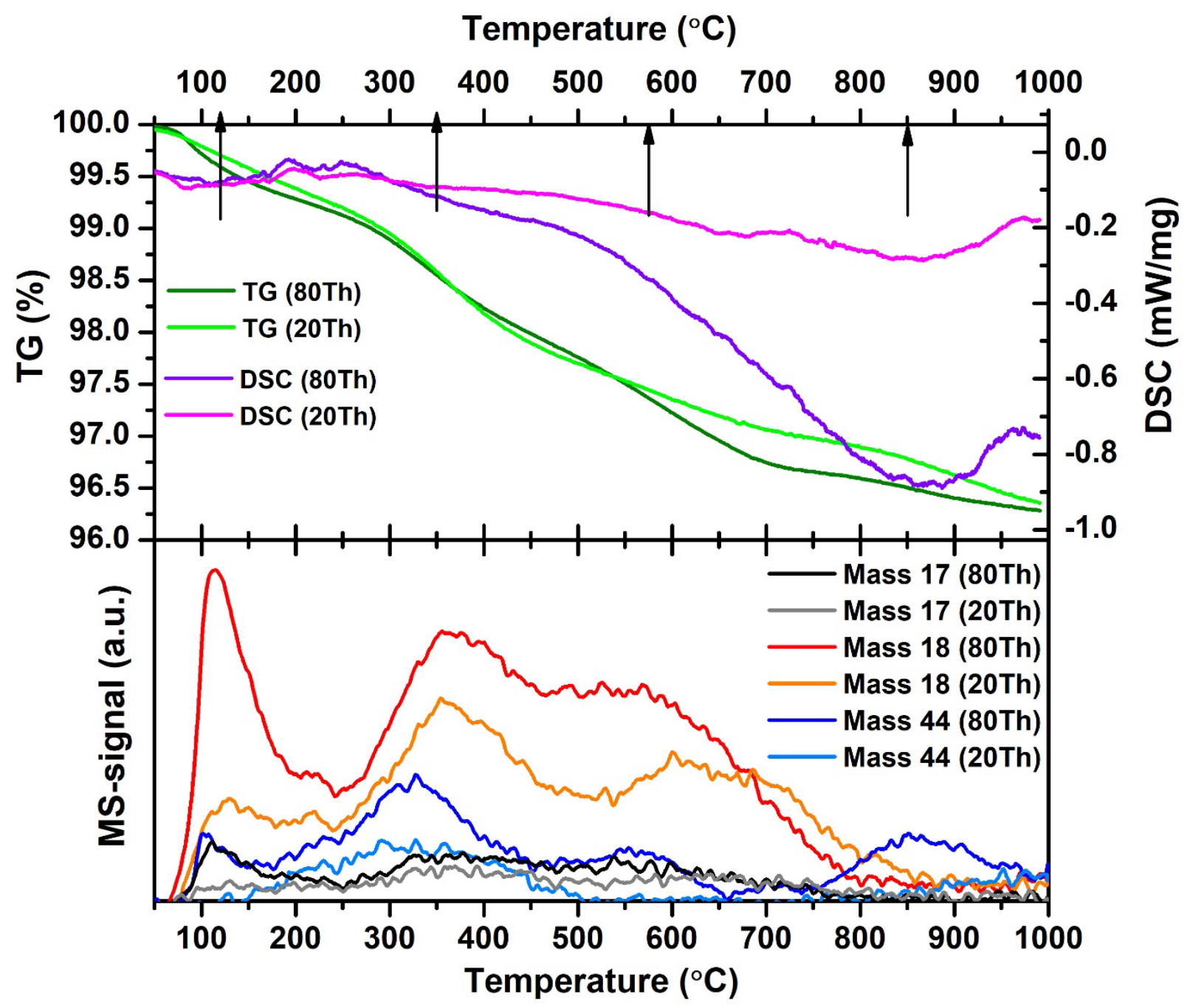

Figure 1. TGA-DSC scans with exothermic direction up (top) and MS signals (bottom) obtained for $20 \mathrm{Th}$ and $80 \mathrm{Th}$ samples. The arrows point to the temperatures of MS-peaks.

During annealing, the samples experienced a stepwise mass loss of 3-5 wt.\% without any significant heat signal at low temperatures, which was surprising considering the coupled results from massspectrometry showing $\mathrm{H}_{2} \mathrm{O}$ loss (signal from mass 18). Other possible species could be $\mathrm{NH}_{3}$ (mass 17) and $\mathrm{CO}_{2}$ (mass 44). Water loss is accompanied by heat uptake that is usually well defined in the DSC scans. The apparent weakness of this endotherm might be a result of possible exothermic processes (from crystallization of the secondary phases) occurring simultaneously. Another possible explanation could be the relatively small grain size of the samples that could also affect the desorption energetics and kinetics and move some of the water loss to the broad peaks at higher temperatures $(\sim$ $700{ }^{\circ} \mathrm{C}$ ). A portion of water present in the samples is the consequence of high surface area leading to 
significant surface adsorbed water where SEM of $\mathrm{Th}_{\mathrm{x}} \mathrm{Er}_{1-\mathrm{x}}\left(\mathrm{SiO}_{4}\right)_{\mathrm{x}}\left(\mathrm{PO}_{4}\right)_{1-\mathrm{x}}$ performed in another study ${ }^{37}$ revealed the presence of nanometric sized needle-shaped grains (200 - $800 \mathrm{~nm}$ in length). The other portion of water which was only removed at higher temperature above $200{ }^{\circ} \mathrm{C}$ could be due to confinement inside the crystal structure (along the c-axis channel), which has been demonstrated in a previous structural study on $\mathrm{CeSiO}_{4}$ and $\mathrm{USiO}_{4}$, isostructural to $\mathrm{Th}_{\mathrm{x}} \mathrm{Er}_{1-\mathrm{x}}\left(\mathrm{SiO}_{4}\right)_{\mathrm{x}}\left(\mathrm{PO}_{4}\right)_{1-\mathrm{x} \cdot}{ }^{45}$ The calculated mole fraction of adsorbed water (assuming that the mass loss coming from other species is negligible) varies around 0.5 mole $\mathrm{H}_{2} \mathrm{O}$ per mole of sample regardless of composition (see Table 2). The suggested presence of small amounts of ammonia and carbonaceous gases could be the result of the low temperature synthesis.

\section{Powder X-Ray Diffraction}

The structures of as prepared and post TGA-DSC (annealed at $1000{ }^{\circ} \mathrm{C}$ ) samples were studied using PXRD. The PXRD patterns of the as-prepared and annealed samples are given in Figure 2.

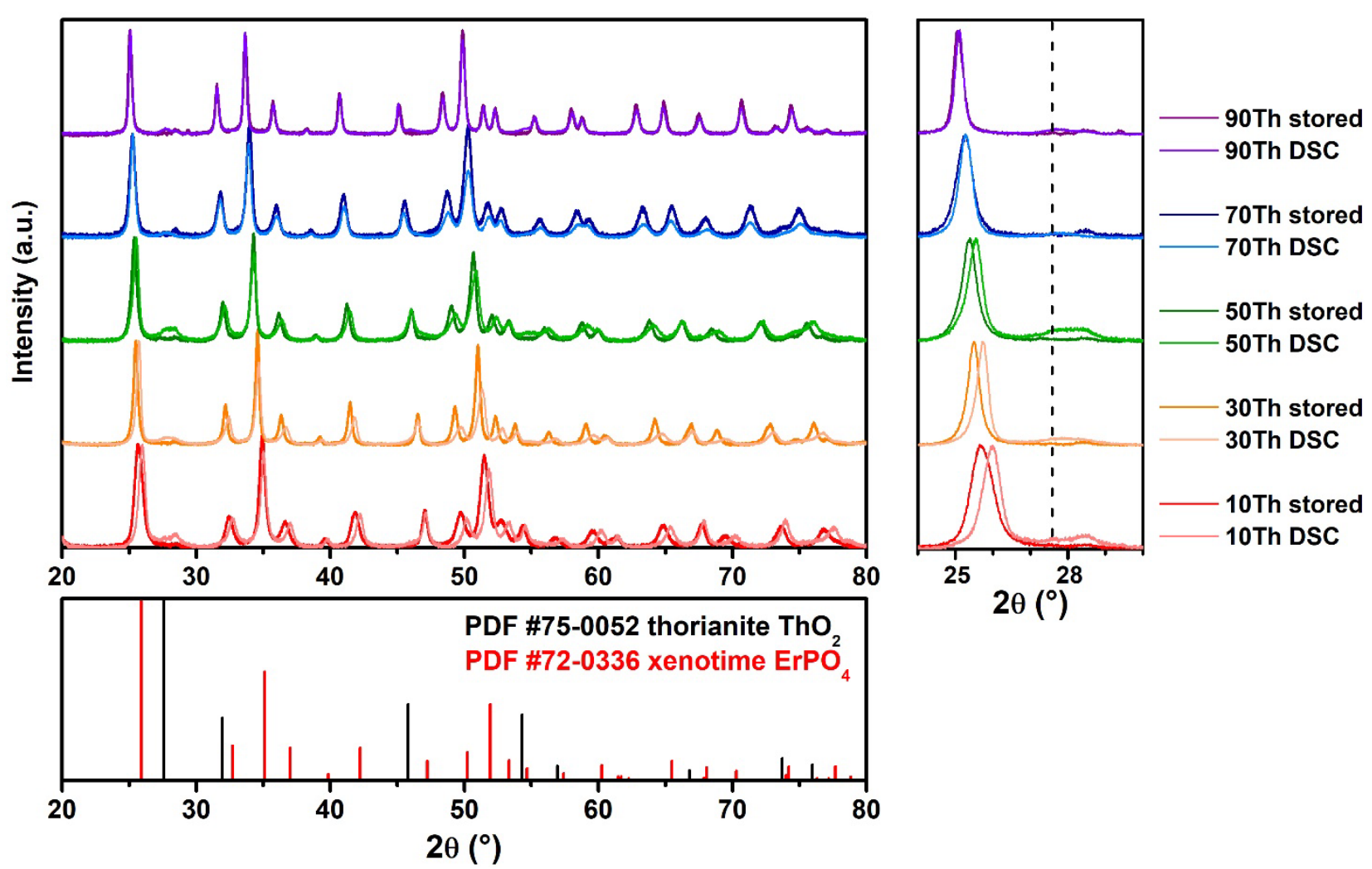

Figure 2. (Top) XRD scans of samples before (as prepared) and after heat treatment (DSC) with the insert of zoomed $24-30^{\circ} 2 \theta$ region (dashed line represents reflections assigned to $\mathrm{ThO}_{2}$ ). (Bottom) PDFs of the xenotime $\mathrm{ErPO}_{4}$ and fluorite $\mathrm{ThO}_{2}$ (thorianite), which is the impurity phase.

For the "stored" samples, the peaks exhibit broadening due to the nanosized character of the materials. In addition, extra reflections were noticeable. First, they could result from the formation of a secondary phase. The PXRD suggests it may be cubic thorianite, $\mathrm{ThO}_{2}$. According to a recent study on thorium silicate $\left(\mathrm{ThSiO}_{4}\right),{ }^{46}$ thorianite was also observed, as a minor phase, during the synthesis of $\mathrm{ThSiO}_{4}$ at lower $\mathrm{pH}$. It must be noted that the thorianite phase was not present on the scans reported in the previous work by Mesbah et al. ${ }^{37}$. In the present study, the $\operatorname{Th}_{\mathrm{x}} \mathrm{Er}_{1-\mathrm{x}}\left(\mathrm{SiO}_{4}\right)_{\mathrm{x}}\left(\mathrm{PO}_{4}\right)_{1-\mathrm{x}}$ samples 
were stored for two years prior to the TGA-DSC and high temperature solution calorimetry experiments. Consequently, $\mathrm{ThO}_{2}$ might have been formed as poorly crystalline material, nevertheless noticeable on "stored" scans and then crystallized and/or coarsened after heating to 1000 ${ }^{\circ} \mathrm{C}$ on "DSC" scans. This is possible according to the equilibrium similar to other silicates. ${ }^{44,47}$

$$
\mathrm{ThSiO}_{4} \rightleftarrows \mathrm{ThO}_{2}+\mathrm{SiO}_{2}
$$

where thorianite is crystallized and silica remains amorphous that is not sensitive to XRD. The Rietveld refinement of the phase composition resulted in average of $\sim 2-4 \mathrm{wt} . \%$ of $\mathrm{ThO}_{2}$ and up to $\sim 11$ wt.\% in some samples (see Table 2). The obtained values do not correlate with the overall Thcontent in the samples from EDX and do not account for all the reflections seen in Figure 2. Although they could not be refined well, the unidentified reflections might be attributed to possible solid solution of $\mathrm{Er}_{2} \mathrm{O}_{3}$ in $\mathrm{ThO}_{2}$ that would shift the peaks to higher angles. Solid solutions of thoria with rare earth elements are known and have been studied before. ${ }^{48,49}$

Another possible explanation of the emerging extra reflections at lower angles could come from the ordering of the defects. Although such effects were not discussed in these systems before, several studies discussed superstructure ordering on the anion sublattice (i.e. defect fluorite - pyrochlore weberite $^{50,51}$ or fluorite - bixbyite ${ }^{52}$ ) and the cation sublattice (i.e. spinels ${ }^{53}$ ). In the Th-Er xenotime system, the incorporation of $\mathrm{Er}^{3+}$ into thorite structure would result in the formation of the oxygen vacancies for charge balance if there was not enough phosphorus in the system. If the sample composition was initially stoichiometric but had exsolved thoria as suggested by PXRD, the remaining xenotime would be Er-enriched, which could be consistent with such possible defect chemistry. Moreover, after the heat treatment, the positions of the main peaks moved to slightly higher angles (smaller lattice parameters). According to a previous study on $\mathrm{CeSiO}_{4}$, isostructural to $\mathrm{Th}_{\mathrm{x}} \mathrm{Er}_{1-\mathrm{x}}\left(\mathrm{SiO}_{4}\right)_{\mathrm{x}}\left(\mathrm{PO}_{4}\right)_{1-\mathrm{x}}$, this was partially due to the removal of confined water that led to the contraction of unit cell volume. ${ }^{45}$

The changes in unit cell parameters and volume as a function of Th-content in the samples are reported in Figure 3. The unit cell parameters $a$ and $c$ both decreased linearly with that of the Thcontent in both series of samples. However, the parameter $a$ changed more steeply in the annealed samples. This resulted in decrease of the unit cell volume of the annealed samples compared to the stored samples. Moreover, this difference only affected samples with low Th-content, becoming almost negligible for Th-content $>0.6$. Such behavior in the Th-poor end could reflect defect and $\mathrm{PO}_{4}{ }^{3-}$ polyhedral ordering. 

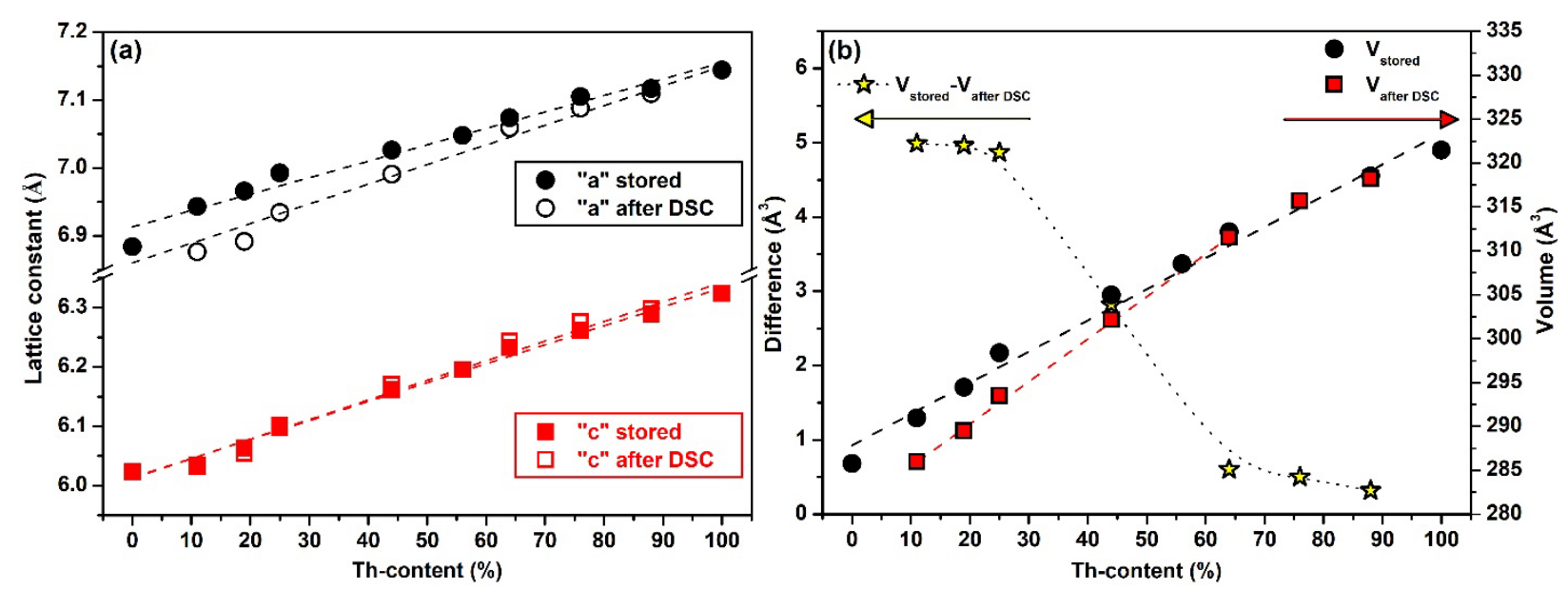

Figure 3. (a) Variation of the unit cell parameters $a$ and $c$ versus the thorium content in the prepared samples before (filled symbols) and after (open symbols) heat treatment at $1000{ }^{\circ} \mathrm{C}$; (b) Variation of the unit cell volume versus the thorium content. The dotted curve was drawn to guide the eye while dashed lines correspond to linear fits of the obtained data. The error bars for this figure are within $\pm 0.0005 \AA$ and overlap with the symbols, therefore we have omitted them.

Table 2. Extra components in the samples as estimated by TGA and XRD analysis.

\begin{tabular}{cccc}
\hline \multirow{2}{*}{ Sample name } & $\begin{array}{c}\text { Water content } \\
\text { from TGA }\end{array}$ & \multicolumn{2}{c}{ ThO $_{\mathbf{2}}$ content from XRD } \\
\cline { 3 - 4 } & $0.787^{*}$ & Stored & After heating in DSC \\
\hline 10Th & 0.503 & 0.017 & 0.107 \\
20Th & 0.461 & 0.030 & 0.144 \\
30Th & 0.497 & 0.046 & 0.199 \\
$50 \mathrm{Th}$ & 0.501 & 0.071 & 0.193 \\
$70 \mathrm{Th}$ & 0.568 & 0.022 & 0.058 \\
80Th & 0.525 & 0.025 & 0.139 \\
90Th & 0.089 & 0.106 \\
\hline
\end{tabular}

${ }^{*}$ This sample also exhibited large exothermic effect presumably coming from some organic impurities

In situ high temperature PXRD measurements were carried out on a separately synthesized $\mathrm{Th}_{0.2} \mathrm{Er}_{0.8}\left(\mathrm{SiO}_{4}\right)_{0.2}\left(\mathrm{PO}_{4}\right)_{0.8}$ sample to determine the structural stability as a function of temperature. (Figure 4). Figure 4 shows that small shoulder peaks appeared around $2 \theta=27.7$ and $46^{\circ}$ above 800 ${ }^{\circ} \mathrm{C}$, indicating the formation of thorianite. This peak due to $\mathrm{ThO}_{2}$ increased in intensity with increasing temperature and indicates the increase in the crystallinity of $\mathrm{ThO}_{2}$, which was confirmed by Rietveld refinement of the sample heated at $1100{ }^{\circ} \mathrm{C}$ (Figure 5 and Figure 6). At $1100{ }^{\circ} \mathrm{C}$, a new set of diffraction peaks emerged (including the obvious peak at $30^{\circ}$ ), which could be due to the formation of huttonite, either from the transformation of decomposed thorite or the reaction of $\mathrm{ThO}_{2} \mathrm{with}_{\mathrm{SiO}}$. This experiment also showed that there are no secondary phases in the "fresh" samples (as reported in ${ }^{37}$ ) compared to those studied after a prolonged storage time (Figure 2). 


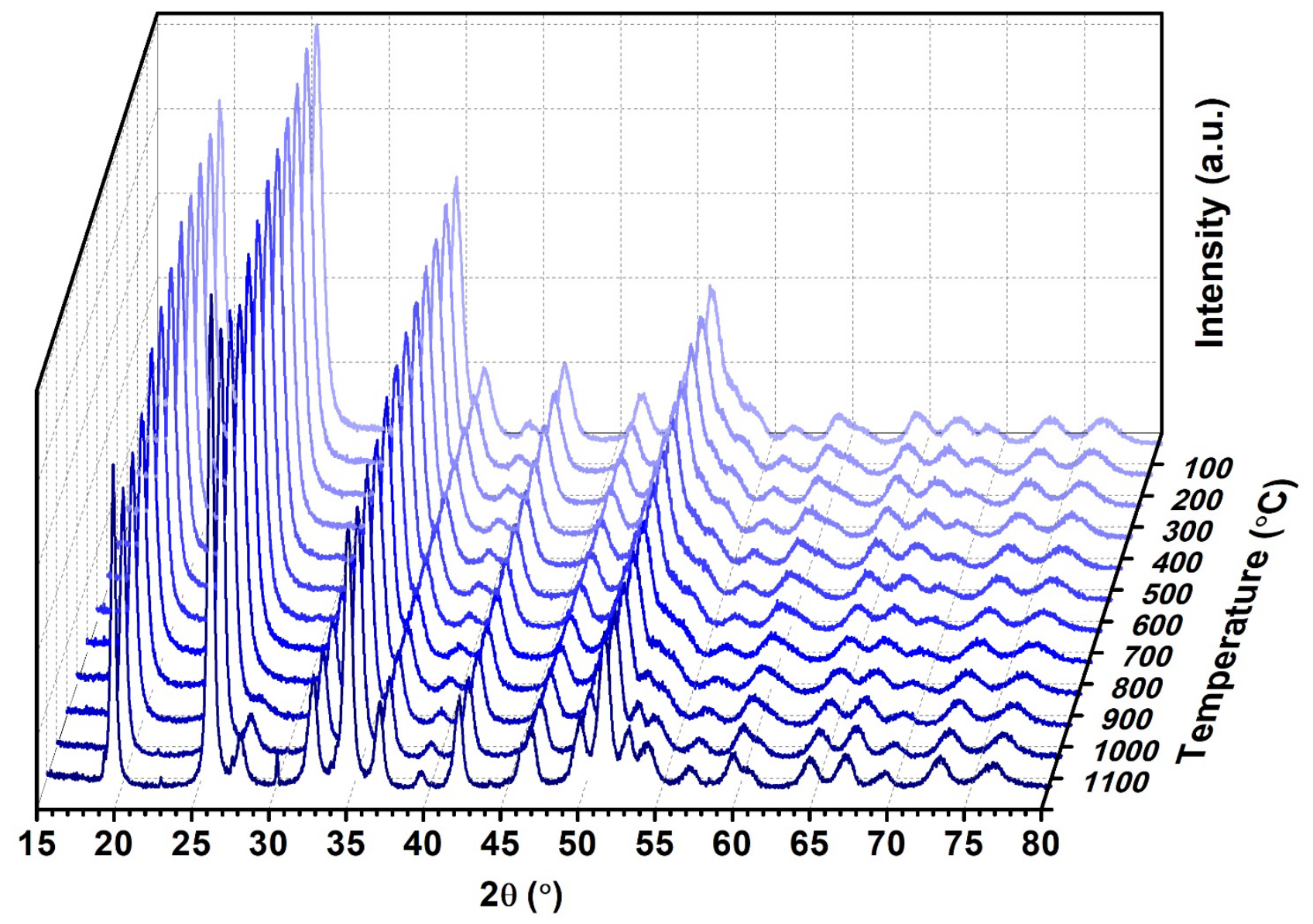

Figure 4. In situ PXRD patterns of $\mathrm{Th}_{0.2} \mathrm{Er}_{0.8}\left(\mathrm{SiO}_{4}\right)_{0.2}\left(\mathrm{PO}_{4}\right)_{0.8}$ from 25 to $1100{ }^{\circ} \mathrm{C}$. 


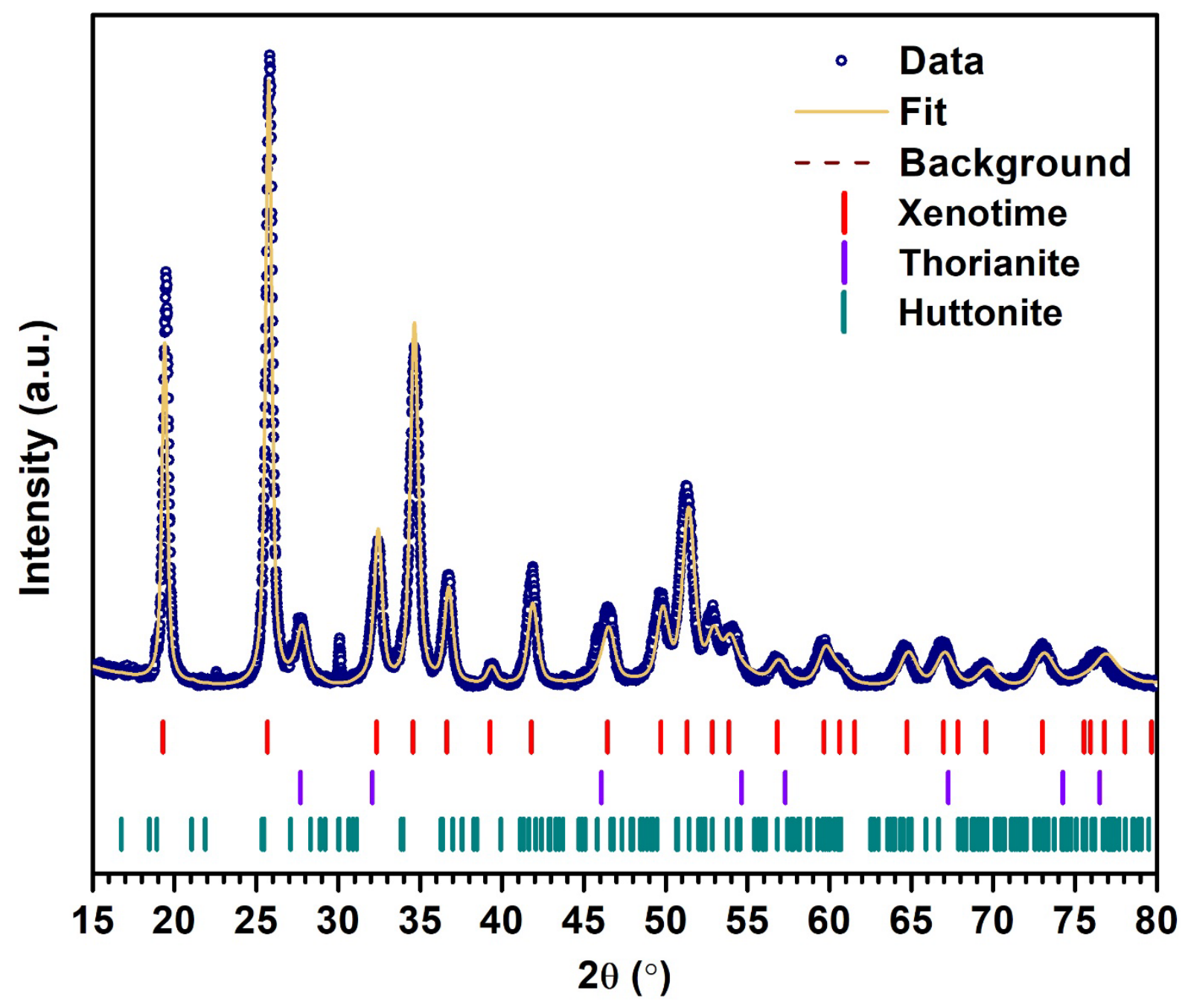

Figure 5. Fitted PXRD pattern of $\mathrm{Th}_{0.2} \mathrm{Er}_{0.8}\left(\mathrm{SiO}_{4}\right)_{0.2}\left(\mathrm{PO}_{4}\right)_{0.8}$ at $1100{ }^{\circ} \mathrm{C}$. Data are shown as open blue circles. The fitting excludes the minor huttonite phase, which was poorly crystalized.
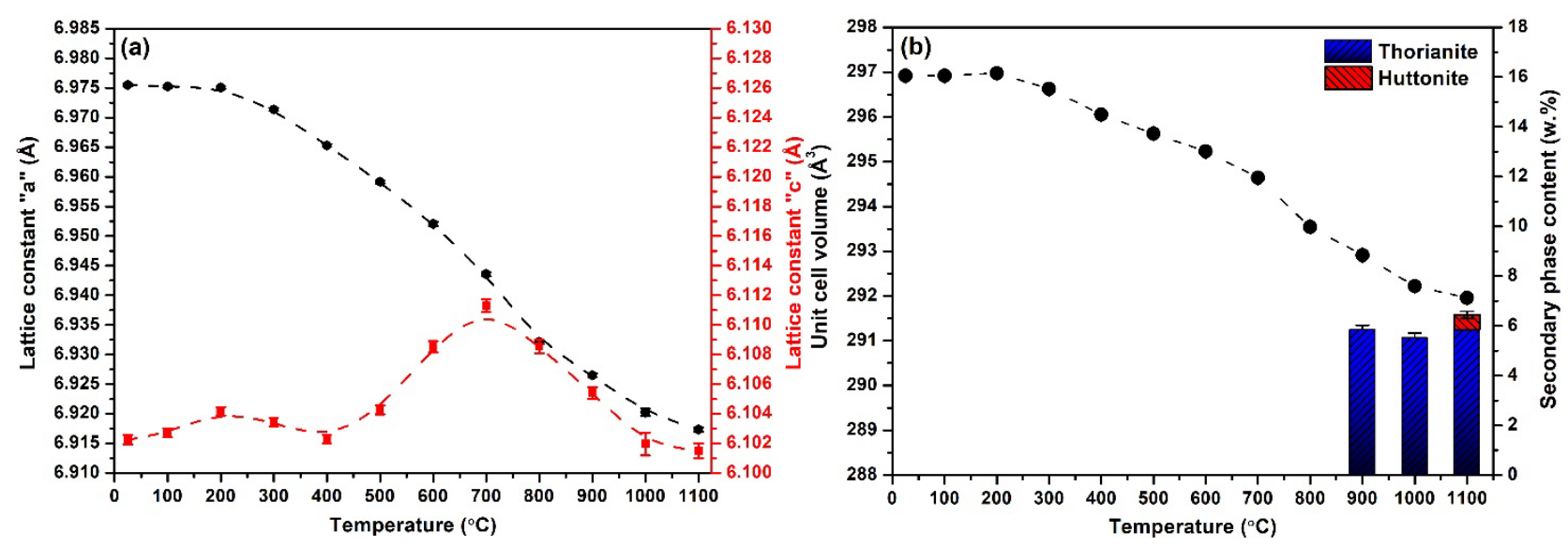

Figure 6. (a) Variation of unit cell parameters for $\mathrm{Th}_{0.2} \mathrm{Er}_{0.8}\left(\mathrm{SiO}_{4}\right)_{0.2}\left(\mathrm{PO}_{4}\right)_{0.8}$; and (b) Variation of unit cell volume and content of secondary phases $\left(\mathrm{ThO}_{2}\right.$ and huttonite), as the function of temperature.

Increase in temperature reveals nonlinear and anisotropic behavior of the unit cell parameters (Figure 6). The unit cell parameter $a$ remained almost unchanged until $200{ }^{\circ} \mathrm{C}$, then decreased, while the parameter $c$ expanded until $700{ }^{\circ} \mathrm{C}$, then decreased at high temperatures. Similar nonlinear thermal 
behavior was reported for $\mathrm{CeSiO}_{4}$ by Strzelecki et $a l,{ }^{45}$ which has a lattice contraction in the $a-(b-)$ axis that was attributed to the removal of confined water from the [001] channels. This finding also agrees with the TG-DSC-MS data (Figure 1) where the evolution of several gases is reported. This leads to lattice parameter "c" expansion and contraction. The overall contraction of the unit cell is possibly a consequence of material sintering upon heating. Similar to this work, previous studies also reported the decomposition of xenotime (zircon) phase into a fluorite phase. ${ }^{45,54}$

\section{Infrared Spectra}

Solid-state ATR-FTIR spectra before and after DSC for the sample 30Th are presented in Figure 7.

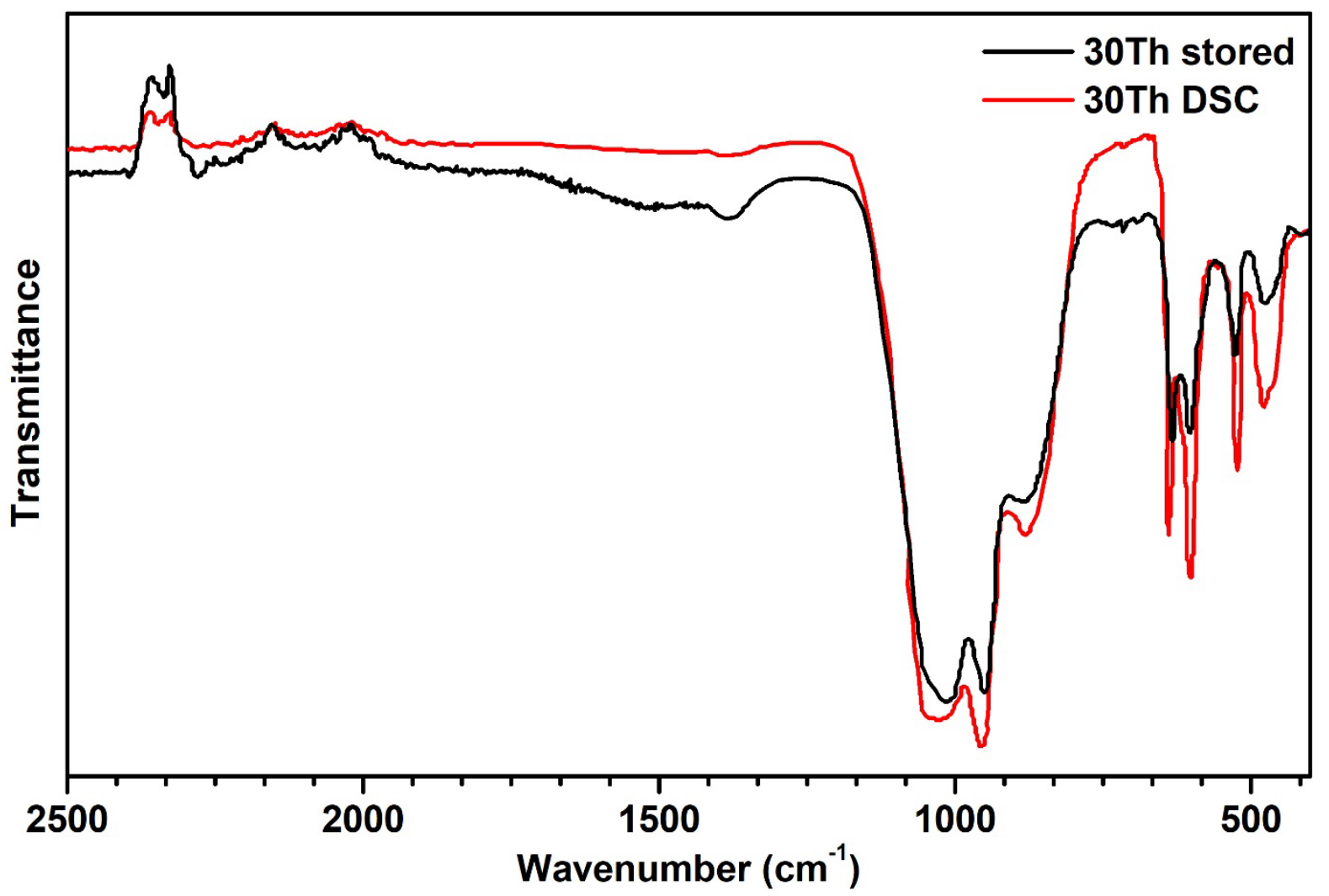

Figure 7. Solid-state ATR-FTIR spectra of sample $\mathrm{Th}_{0.3} \mathrm{Er}_{0.7}\left(\mathrm{SiO}_{4}\right)_{0.3}\left(\mathrm{PO}_{4}\right)_{0.7}$ before and after DSC.

The bands associated with water $\left(1400-2100 \mathrm{~cm}^{-1}\right)$ and carbonate $\left(2200-2400 \mathrm{~cm}^{-1}\right)$ are smaller after the heat treatment, consistent with degassing upon heating. The $\mathrm{PO}_{4}{ }^{3-}$ and $\mathrm{SiO}_{4}{ }^{4-}$ bands $(700-$ $\left.1200 \mathrm{~cm}^{-1}\right)$ are larger and some of their features $\left(850 \mathrm{~cm}^{-1}\right.$ and $\left.1050 \mathrm{~cm}^{-1}\right)$ are sharper. This may imply that local ordering of $\mathrm{PO}_{4}{ }^{3-}$ and $\mathrm{SiO}_{4}{ }^{4-}$ polyhedra increases after heat treatment. It was shown in the previous study that the shape of these features changes with increase in Th-content ${ }^{37}$.

\section{High Temperature Oxide Melt Solution Calorimetry}

The enthalpies of drop solution $\left(\boldsymbol{\Delta} \boldsymbol{H}_{\mathrm{ds}}\right)$ of the stored and annealed samples are given in Table 3. As these samples contain both adsorbed water and some oxide impurities, their amounts have been accounted for in the thermochemical cycle (see Table 4 for the details of correction). The corrected 
values are also given in Table $\mathbf{3}$ along with the calculated values of the enthalpies of mixing $\left(\Delta \boldsymbol{H}_{\text {mix }}\right)$ and formation from oxides $\left(\boldsymbol{\Delta} \boldsymbol{H}_{\mathbf{f}, \mathbf{o x}}\right)$. The measured values are plotted in Figure $\boldsymbol{8}$ along with those of the stable zircon-type structure end members, xenotime $\mathrm{ErPO}_{4}$ and thorite $\mathrm{ThSiO}_{4}$.

Table 3. Solution calorimetric data for the samples before and after DSC: enthalpy of drop solution as measured $\left(\boldsymbol{\Delta} \boldsymbol{H}_{\mathrm{ds}}\right)$, enthalpy of drop solution corrected for water $\left(\boldsymbol{\Delta} \boldsymbol{H}_{\text {ds }}\right.$ (stored)), enthalpy of drop solution corrected for the presence of $\mathrm{ThO}_{2}\left(\boldsymbol{\Delta} \boldsymbol{H}^{*}\right.$ ds $\left.(\mathbf{D S C})\right)$, enthalpy of mixing $\left(\boldsymbol{\Delta} \boldsymbol{H}_{\text {mix }}\right)$ and enthalpy of formation from oxides $\left(\Delta \boldsymbol{H}_{\mathbf{f}, \mathbf{o x}}\right)$.

\begin{tabular}{|c|c|c|c|c|c|c|c|c|}
\hline \multirow[b]{2}{*}{$\begin{array}{l}\text { Sample } \\
\text { name }\end{array}$} & \multicolumn{4}{|c|}{ Before DSC } & \multicolumn{4}{|c|}{ After DSC } \\
\hline & $\begin{array}{c}\Delta \mathbf{H}_{\mathrm{ds}}(\text { stored }) \\
\mathrm{kJ} / \mathrm{mol}\end{array}$ & $\begin{array}{c}\Delta \mathbf{H}_{\mathrm{ds}}^{*}(\text { stored }) \\
\mathrm{kJ} / \mathrm{mol}\end{array}$ & $\begin{array}{c}\Delta H_{\text {mix }}(\text { stored }) \\
\mathrm{kJ} / \mathrm{mol}\end{array}$ & $\begin{array}{c}\Delta \mathbf{H}_{\mathrm{f}, \mathrm{ox}}(\text { stored }) \\
\mathrm{kJ} / \mathrm{mol}\end{array}$ & $\begin{array}{c}\Delta \mathbf{H}_{\mathrm{ds}}(\mathrm{DSC}) \\
\mathrm{kJ} / \mathrm{mol}\end{array}$ & $\begin{array}{c}\Delta \mathbf{H}^{*}{ }_{\mathrm{ds}}(\mathrm{DSC}) \\
\mathrm{kJ} / \mathrm{mol}\end{array}$ & $\begin{array}{c}\Delta \mathrm{H}_{\operatorname{mix}}(\mathrm{DSC}) \\
\mathrm{kJ} / \mathrm{mol}\end{array}$ & $\begin{array}{c}\Delta \mathbf{H}_{\mathrm{f}, \mathrm{ox}}(\mathrm{DSC}) \\
\mathbf{k J} / \mathbf{m o l}\end{array}$ \\
\hline $\mathrm{ErPO}_{4}$ & $129.85^{\S}$ & - & - & $-275.6 \pm 1.9^{55}$ & 129.85 & 129.85 & 0 & $-275.6 \pm 1.9$ \\
\hline Th10 & $160.10 \pm 1.65(7)$ & $117.60 \pm 1.65$ & $15.0 \pm 2.4$ & $-231.0 \pm 5.6$ & $142.21 \pm 1.18(2)$ & $131.72 \pm 1.18$ & $0.8 \pm 2.1$ & $-245.2 \pm 5.4$ \\
\hline Th20 & $186.28 \pm 0.42(6)$ & $140.50 \pm 0.42$ & $-6.0 \pm 2.4$ & $-230.4 \pm 5.1$ & $151.12 \pm 2.32(2)$ & $136.98 \pm 2.32$ & $-2.5 \pm 3.3$ & $-226.9 \pm 5.6$ \\
\hline Th30 & $172.26 \pm 1.98(6)$ & $132.14 \pm 1.98$ & $3.9 \pm 3.3$ & $-204.5 \pm 5.3$ & $150.06 \pm 1.70(2)$ & $130.55 \pm 1.70$ & $5.4 \pm 3.2$ & $-202.9 \pm 5.2$ \\
\hline Th50 & $176.79 \pm 1.12(6)$ & $129.91 \pm 1.12$ & $10.7 \pm 3.8$ & $-146.4 \pm 4.5$ & $154.91 \pm 2.01(2)$ & $135.93 \pm 2.01$ & $4.7 \pm 4.1$ & $-152.4 \pm 4.8$ \\
\hline Th70 & $181.64 \pm 0.66(6)$ & $141.88 \pm 0.66$ & $3.7 \pm 4.4$ & $-99.6 \pm 3.7$ & $150.17 \pm 0.99(2)$ & $144.52 \pm 0.99$ & $1.0 \pm 4.4$ & $-102.3 \pm 3.8$ \\
\hline Th80 & $202.18 \pm 0.40(5)$ & $154.38 \pm 0.40$ & $-1.8 \pm 4.7$ & $-72.8 \pm 3.2$ & $179.22 \pm 2.41(3)$ & $165.60 \pm 2.41$ & $-17.1 \pm 5.3$ & $-88.1 \pm 4.0$ \\
\hline Th90 & $204.08 \pm 1.55(6)^{\#}$ & $154.40 \pm 1.55$ & $-2.9 \pm 5.3$ & $-41.6 \pm 3.0$ & $174.14 \pm 1.96(3)$ & $163.77 \pm 1.96$ & $-12.3 \pm 5.4$ & $-51.0 \pm 3.2$ \\
\hline $\mathrm{ThSiO}_{4}$ & $154.40 \pm 5.4^{54}$ & - & - & $-6.4 \pm 5.7^{54}$ & $154.40 \pm 5.40$ & - & 0 & $-6.4 \pm 5.7$ \\
\hline
\end{tabular}

*values, corrected for water (as is) and $\mathrm{ThO}_{2}$ (after DSC) content

\#this value might not reflect the general trend due to the presence of possible impurities

${ }^{\$}$ This value is synthetic as it was back-calculated from the enthalpy of formation $\left(-275.6 \pm 1.9 \mathrm{~kJ} / \mathrm{mol}^{55}\right)$

The remaining small differences, after correction for water and impurity phases, obtained between stored and annealed samples could arise from a combination of other effects, such as the slight grain growth and/or ordering of defects either from charge balance or exsolution of $\mathrm{ThO}_{2}$. However, the overall heat effect of dissolution was not strongly affected by heating to $1000{ }^{\circ} \mathrm{C}$ in DSC and the values for annealed and stored samples lie within likely experimental error, especially when one considers possible changes in composition and exsolution in addition to the statistical error of the calorimetric measurements. Despite these small differences, we can state that the thorite-xenotime solid solution was stable with respect to binary oxides but showed a complex (nominally subregular) enthalpy of mixing.
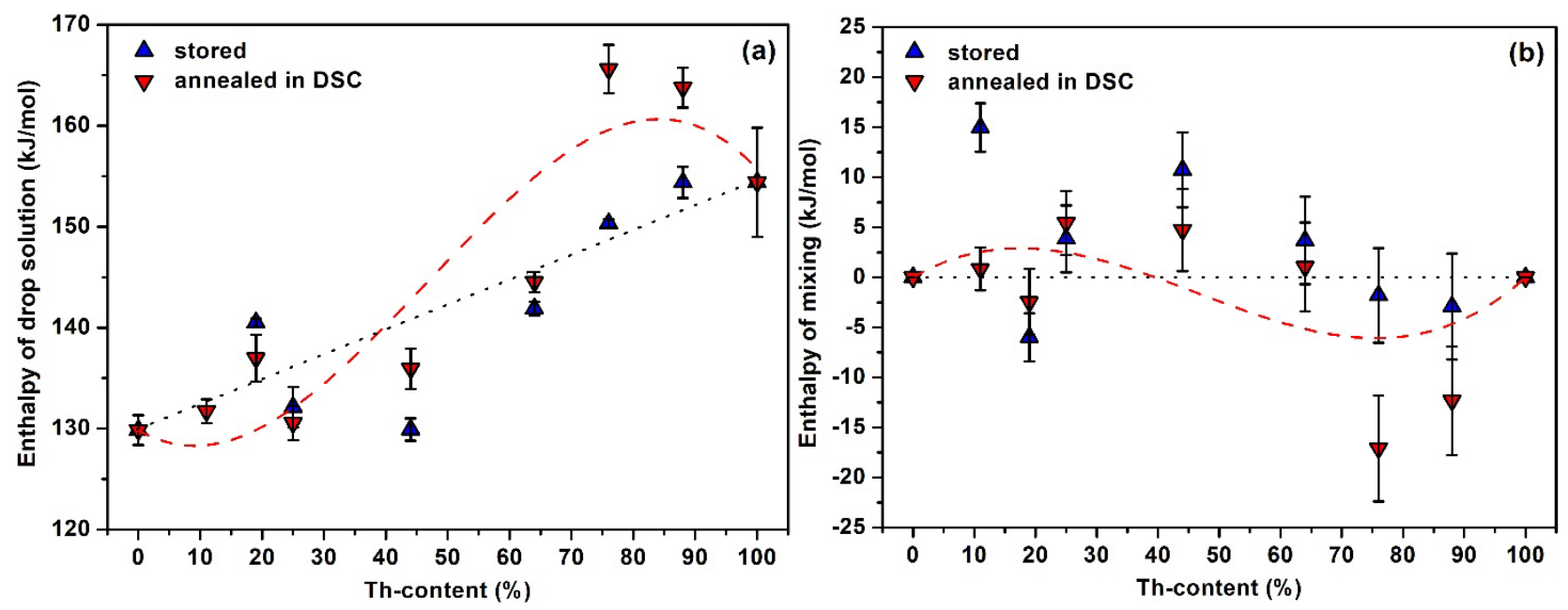

Figure 8. (a) Enthalpy of drop solution of stored samples and samples after DSC. (b) Enthalpy of mixing of the stored samples and samples after DSC. Dashed curves represent polynomial fits using the whole set of data. Dotted lines represent zero heat of mixing. 
Fitting both series of data together requires the subregular solution model. Heats of mixing are slightly endothermic on the thorium-depleted side and slightly exothermic on the thorium-enriched side. The interaction is not large. Indeed, mixing enthalpies are mainly less than $15 \mathrm{~kJ} / \mathrm{mol}$ in magnitude. Thus, there is a little driving force for exsolution or ternary phase formation and the solid solutions can be viewed as continuous at all accessible temperatures. Margules parameters can be estimated from the fitted polynomial function:

$$
\Delta H_{\text {mix }}=W(x) \cdot x \cdot(1-x)=\left(W_{1} \cdot(1-x)+W_{2} \cdot x\right) \cdot x \cdot(1-x),
$$

from which $\mathrm{W}_{1}=73.1 \pm 20.1 \mathrm{~kJ} / \mathrm{mol}$ and $\mathrm{W}_{2}=-52.6 \pm 45.6 \mathrm{~kJ} / \mathrm{mol}$ and the overall Margules function is:

$$
W(x)=(73.1 \pm 20.1)-(125.7 \pm 49.8) \cdot x
$$

This complex energetic behavior may reflect the simultaneous substitution of silicon and phosphorus and of thorium and erbium on different sites in the crystal structure and possible short-range order as observed previously by Mesbah et al. ${ }^{37}$ Indeed, it has been shown that the Th-O distances do not evolve in the same way as the Er-O distances in the thorite-xenotime solid solution.

Table 4. Thermochemical cycle used to calculate water correction for the enthalpies of drop solution and for the calculation of the enthalpy of formation from oxides.

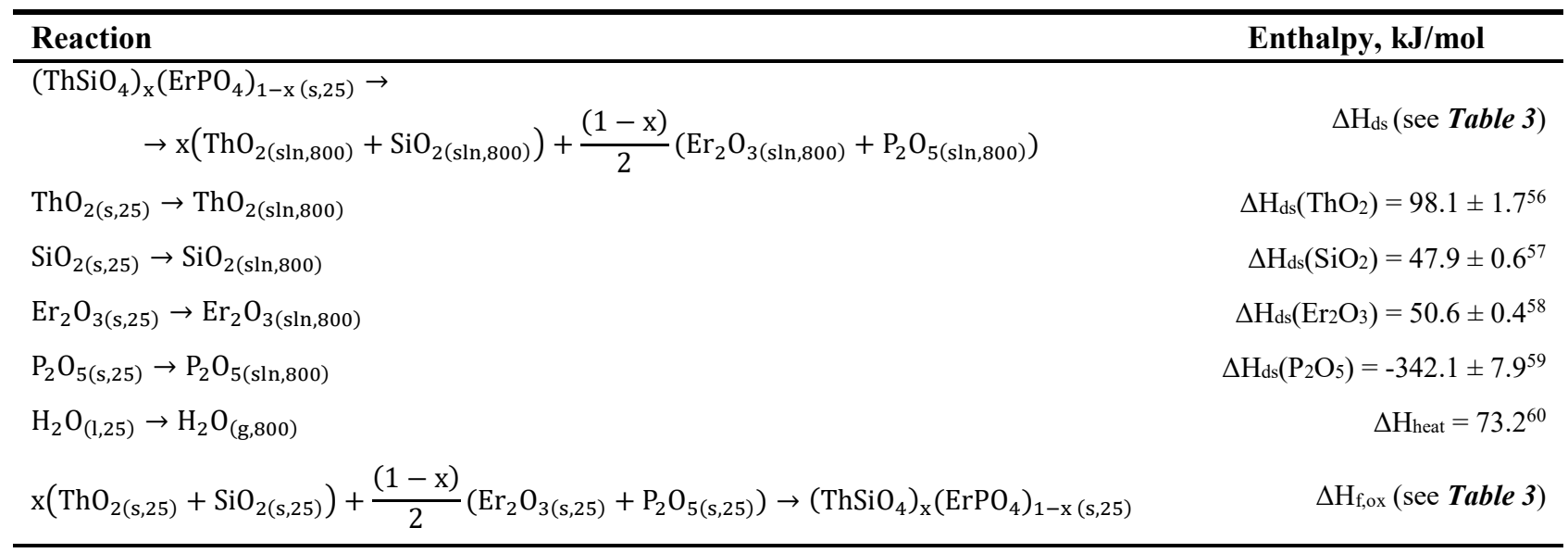

Correction for water:

$$
\Delta H_{d s}^{*}=\Delta H_{d s^{-}} n \times \Delta H_{\text {heat }}
$$

Enthalpy of formation from oxides:

$$
\Delta H_{f, o x}=-\Delta H_{d s}^{*}+x \times\left[\Delta H_{d s}\left(\mathrm{ThO}_{2}\right)+\Delta H_{d s}\left(\mathrm{SiO}_{2}\right)\right]+\frac{(1-\mathrm{x})}{2} \times\left[\Delta H_{d s}\left(\mathrm{Er}_{2} \mathrm{O}_{3}\right)+\Delta H_{d s}\left(\mathrm{P}_{2} \mathrm{O}_{5}\right)\right]
$$

Enthalpy of mixing:

$$
\Delta H_{m i x}=-\Delta H_{d s}^{*}+x \times \Delta H_{d s}\left(\mathrm{ThSiO}_{4}, \text { thorite }\right)+(1-x) \Delta H_{d s}\left(\mathrm{ErPO}_{4}\right)
$$

Enthalpy of formation from oxides was also calculated through a thermodynamic cycle and the resulting values are given in Table 3 and plotted in Figure 9. 


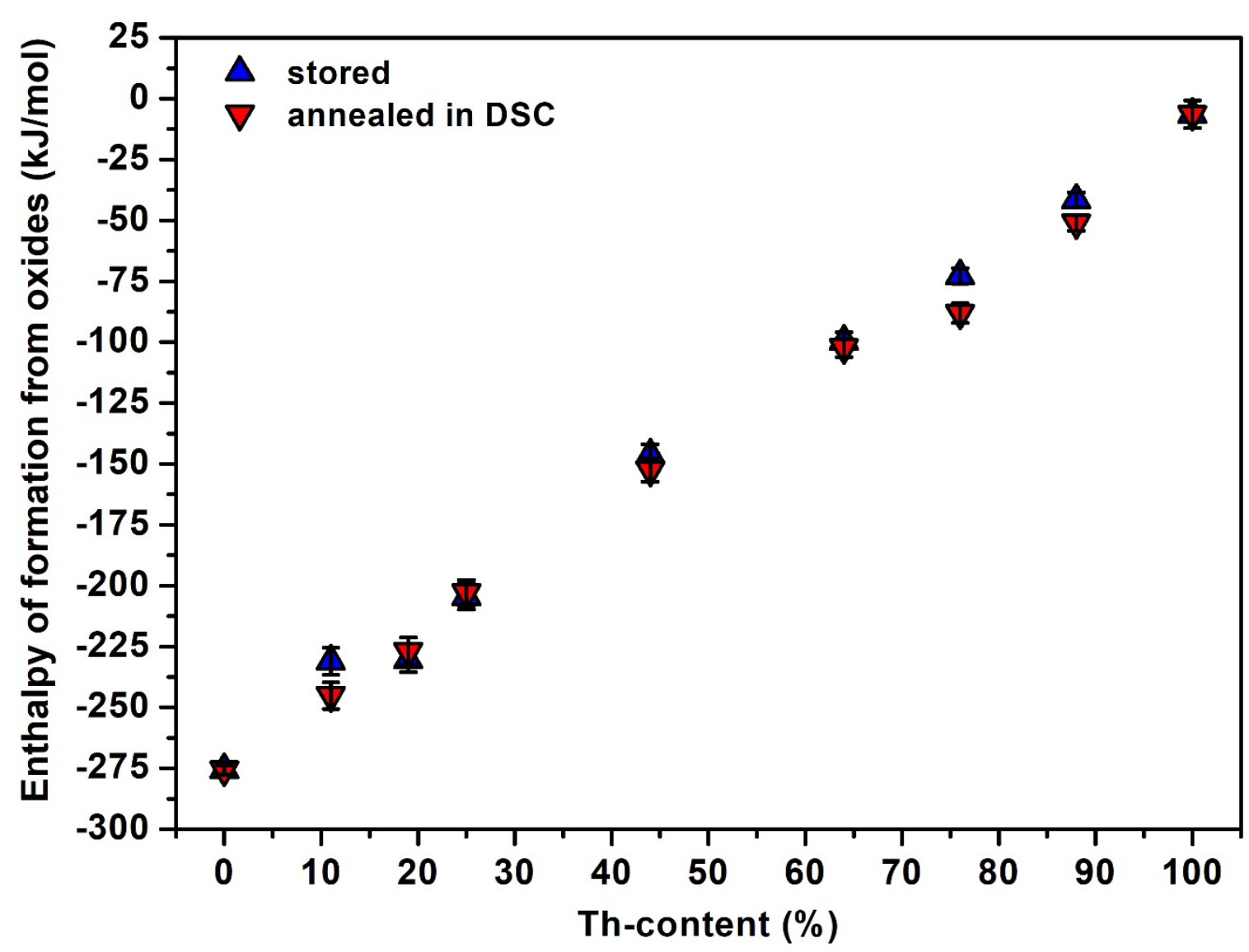

Figure 9. Enthalpy of formation from oxides before and after DSC.

The approximately linear trend in Figure 9 indicates that the small mixing enthalpies are masked by the large approximately linear destabilization with increasing Th-content. This destabilization reflects the greater stability or the phosphate endmember compared to the silicate.

\section{CONCLUSION}

The non-linear unit cell volume expansion is a feature of the zircon-type structure shown for several similar systems. It is also common that upon heating, such materials mainly maintain the I $_{1} /$ amd symmetry, but after $700{ }^{\circ} \mathrm{C}$, the fluorite phase can evolve. The $\mathrm{ThSiO}_{4}-\mathrm{ErPO}_{4}$ system forms a complete solid solution with small, but complex deviations from ideal mixing. This solid solution is predicted to be thermodynamically stable with respect to binary oxides with little driving force for either exsolution or intermediate compound formation, which is essential for a ceramic nuclear waste form. $\mathrm{ErPO}_{4}$ is energetically more stable relative to oxide endmembers than $\mathrm{ThSiO}_{4}$ substantially, resulting in an almost linear trend in enthalpy of formation versus thorianite content.

\section{ACKNOWLEDGMENTS}

The experimental work was supported as part of the Materials Science of Actinides, an Energy Frontier Research Center funded by the U.S. Department of Energy, Office of Science, Basic Energy Sciences under Award Number DE-SC0001089. The last stages of data analysis and manuscript preparation were supported by the U.S. Department of Energy, Office of Basic Energy Sciences, grant DE-FG02-97ER14749. A.S. was supported by state assignment for the Institute of Solid State Chemistry of the Ural Brunch of Russian Academy of Sciences (№ AAAA-A19-119031890029-7). 
X.G. acknowledges the support through the institutional funds from the Department of Chemistry and New Faculty Seed Grant from ORAP at Washington State University. The authors would like to thank the French National Research Agency (ANR JCJC-X-MAS; Project \#ANR-17-CE06-0004) for the financial support.

\section{SUPPORTING INFORMATION}

TGA-DSC scans of the samples studied in this work.

\section{REFERENCES}

(1) Boatner, L. A. Synthesis, Structure, and Properties of Monazite, Pretulite, and Xenotime. Rev. Mineral. Geochemistry 2002, 48 (1), 87-121. https://doi.org/10.2138/rmg.2002.48.4.

(2) Rapp, R. P.; Watson, E. B. Monazite Solubility and Dissolution Kinetics: Implications for the Thorium and Light Rare Earth Chemistry of Felsic Magmas. Contrib. to Mineral. Petrol. 1986, 94 (3), 304-316. https://doi.org/10.1007/BF00371439.

(3) Bowring, S.; Housh, T. The Earth's Early Evolution. Science (80-. ). 1995, 269 (5230), 1535-1540. https://doi.org/10.1126/science.7667634.

(4) Förster, H.-J. Composition and Origin of Intermediate Solid Solutions in the System ThoriteXenotime-Zircon-Coffinite. Lithos 2006, 88 (1-4), 35-55. https://doi.org/10.1016/j.lithos.2005.08.003.

(5) Ni, Y.; Hughes, J. M.; Mariano, A. N. Crystal Chemistry of the Monazite and Xenotime Structures. Am. Mineral. 1995, 80 (1-2), 21-26. https://doi.org/10.2138/am-1995-1-203.

(6) Förster, H.-J. The Chemical Composition of REE-Y-Th-U-Rich Accessory Minerals in Peraluminous Granites of the Erzgebirge-Fichtelgebirge Region, Germany; Part I, The Monazite-(Ce)-Brabantite Solid Solution Series. Am. Mineral. 1998, 83 (3-4), 259-272. https://doi.org/10.2138/am-1998-3-409.

(7) Bea, F. Residence of REE, Y, Th and U in Granites and Crustal Protoliths; Implications for the Chemistry of Crustal Melts. J. Petrol. 1996, 37 (3), 521-552. https://doi.org/10.1093/petrology/37.3.521.

(8) Franz, G.; Andrehs, G.; Rhede, D. Crystal Chemistry of Monazite and Xenotime from Saxothuringian-Moldanubian Metapelites, NE Bavaria, Germany. Eur. J. Mineral. 1996, 8 (5), 1097 1118. https://doi.org/10.1127/ejm/8/5/1097.

(9) Heinrich, W.; Rehs, G.; Franz, G. Monazite-Xenotime Miscibility Gap Thermometry. I. An Empirical Calibration. J. Metamorph. Geol. 1997, 15 (1), 3-16. https://doi.org/10.1111/j.1525-1314.1997.t01-100052.x.

(10) Buick, R.; Brauhart, C. W. W.; Morant, P.; Thornett, J. R. R.; Maniw, J. G. G.; Archibald, N. J. J.; Doepel, M. G. G.; Fletcher, I. R. R.; Pickard, A. L. L.; Smith, J. B. B.; Barley, M. E. E.; McNaughton, N. J. J.; Groves, D. I. I. Geochronology and Stratigraphic Relationships of the Sulphur Springs Group and Strelley Granite: A Temporally Distinct Igneous Province in the Archaean Pilbara Craton, Australia. Precambrian Res. 2002, 114 (1-2), 87-120. https://doi.org/10.1016/S03019268(01)00221-2.

(11) Buick, R.; Thornett, J. R.; McNaughton, N. J.; Smith, J. B.; Barley, M. E.; Savage, M. Record of Emergent Continental Crust 3.5 Billion Years Ago in the Pilbara Craton of Australia. Nature 1995, 375 (6532), 574-577. https://doi.org/10.1038/375574a0.

(12) Schärer, U.; Xu, R.-H. H.; Allègre, C. J. U-Pb Geochronology of Gangdese (Transhimalaya) Plutonism in the Lhasa-Xigaze Region, Tibet. Earth Planet. Sci. Lett. 1984, 69 (2), 311-320. https://doi.org/10.1016/0012-821X(84)90190-0.

(13) Schärer, U. The Effect of Initial ${ }^{230}$ Th Disequilibrium on Young U-Pb Ages: The Makalu Case, Himalaya. Earth Planet. Sci. Lett. 1984, 67 (2), 191-204. https://doi.org/10.1016/0012821X(84)90114-6.

(14) Bowring, S. A.; Erwin, D. H. H.; Jin, Y. G. G.; Martin, M. W. W.; Davidek, K.; Wang, W. U/Pb Zircon Geochronology and Tempo of the End-Permian Mass Extinction. Science (80-. ). 1998, 280 (5366), 1039-1045. https://doi.org/10.1126/science.280.5366.1039.

(15) Gibson, G. M.; Ireland, T. R. Granulite Formation during Continental Extension in Fiordland, New Zealand. Nature 1995, 375 (6531), 479-482. https://doi.org/10.1038/375479a0.

(16) Seydoux-Guillaume, A.-M.; Wirth, R.; Heinrich, W.; Montel, J.-M. Experimental Determination of Thorium Partitioning between Monazite and Xenotime Using Analytical Electron Microscopy and X- 
Ray Diffraction Rietveld Analysis. Eur. J. Mineral. 2002, 14 (5), 869-878.

https://doi.org/10.1127/0935-1221/2002/0014-0869.

(17) Rasmussen, B.; Fletcher, I. R.; Muhling, J. R.; Wilde, S. A. In Situ U-Th-Pb Geochronology of Monazite and Xenotime from the Jack Hills Belt: Implications for the Age of Deposition and Metamorphism of Hadean Zircons. Precambrian Res. 2010, 180 (1-2), 26-46.

https://doi.org/10.1016/j.precamres.2010.03.004.

(18) Rasmussen, B.; Fletcher, I. R.; Muhling, J. R. In Situ U-Pb Dating and Element Mapping of Three Generations of Monazite: Unravelling Cryptic Tectonothermal Events in Low-Grade Terranes. Geochim. Cosmochim. Acta 2007, 71 (3), 670-690. https://doi.org/10.1016/j.gca.2006.10.020.

(19) Montel; Kornprobst; Vielzeuf. Preservation of Old U-Th-Pb Ages in Shielded Monazite: Example from the Beni Bousera Hercynian Kinzigites (Morocco). J. Metamorph. Geol. 2001, 18 (3), 335-342. https://doi.org/10.1046/j.1525-1314.2000.00261.x.

(20) Montel, J.-M.; Razafimahatratra, D.; Ralison, B.; De Parseval, P.; Thibault, M.; Randranja, R. Monazite from Mountain to Ocean: A Case Study from Trolognaro (Fort-Dauphin), Madagascar. Eur. J. Mineral. 2011, 23 (5), 745-757. https://doi.org/10.1127/0935-1221/2011/0023-2149.

(21) Dacheux, N.; Clavier, N.; Podor, R. Versatile Monazite: Resolving Geological Records and Solving Challenges in Materials Science: Monazite as a Promising Long-Term Radioactive Waste Matrix: Benefits of High-Structural Flexibility and Chemical Durability. Am. Mineral. 2013, 98 (5-6), 833 847. https://doi.org/10.2138/am.2013.4307.

(22) Schlenz, H.; Heuser, J.; Neumann, A.; Schmitz, S.; Bosbach, D. Monazite as a Suitable Actinide Waste Form. Zeitschrift für Krist. - Cryst. Mater. 2013, 228 (3), 113-123. https://doi.org/10.1524/zkri.2013.1597.

(23) Terra, O.; Dacheux, N.; Audubert, F.; Podor, R. Immobilization of Tetravalent Actinides in Phosphate Ceramics. J. Nucl. Mater. 2006, 352 (1-3), 224-232. https://doi.org/10.1016/j.jnucmat.2006.02.058.

(24) Bregiroux, D.; Terra, O.; Audubert, F.; Dacheux, N.; Serin, V.; Podor, R.; Bernache-Assollant, D. Solid-State Synthesis of Monazite-Type Compounds Containing Tetravalent Elements. Inorg. Chem. 2007, 46 (24), 10372-10382. https://doi.org/10.1021/ic7012123.

(25) Terra, O.; Dacheux, N.; Clavier, N.; Podor, R.; Audubert, F. Preparation of Optimized Uranium and Thorium Bearing Brabantite or Monazite/Brabantite Solid Solutions. J. Am. Ceram. Soc. 2008, 91 (11), 3673-3682. https://doi.org/10.1111/j.1551-2916.2008.02678.x.

(26) Oelkers, E. H.; Montel, J.-M. Phosphates and Nuclear Waste Storage. Elements 2008, 4 (2), 113-116. https://doi.org/10.2113/GSELEMENTS.4.2.113.

(27) Burakov, B. E.; Yagovkina, M. A.; Garbuzov, V. M.; Kitsay, A. A.; Zirlin, V. A. Self-Irradiation of Monazite Ceramics: Contrasting Behavior of $\mathrm{PuPO}_{4}$ and (La,Pu) $\mathrm{PO}_{4}$ Doped with $\mathrm{Pu}-238$. MRS Proc. 2004, 824, CC4.1. https://doi.org/10.1557/PROC-824-CC4.1.

(28) Ewing, R. C.; Lutze, W.; Weber, W. J. Zircon: A Host-Phase for the Disposal of Weapons Plutonium. J. Mater. Res. 1995, 10 (2), 243-246. https://doi.org/10.1557/JMR.1995.0243.

(29) Ewing, R. C.; Wang, L. Phosphates as Nuclear Waste Forms. Rev. Mineral. Geochemistry 2002, 48 (1), 673-699. https://doi.org/10.2138/rmg.2002.48.18.

(30) Meldrum, A.; Boatner, L. A.; Ewing, R. C. A Comparison of Radiation Effects in Crystalline $\mathrm{ABO}_{4-}$ Type Phosphates and Silicates. Mineral. Mag. 2000, 64 (2), 185-194. https://doi.org/10.1180/002646100549283.

(31) Shelyug, A.; Mesbah, A.; Szenknect, S.; Clavier, N.; Dacheux, N.; Navrotsky, A. Thermodynamics and Stability of Rhabdophanes, Hydrated Rare Earth Phosphates $\mathrm{REPO}_{4} \cdot \mathrm{nH}_{2} \mathrm{O}$. Front. Chem. 2018, 6 (DEC). https://doi.org/10.3389/fchem.2018.00604.

(32) Rafiuddin, M. R.; Seydoux-Guillaume, A.-M.; Deschanels, X.; Mesbah, A.; Baumier, C.; Szenknect, S.; Dacheux, N. An In-Situ Electron Microscopy Study of Dual Ion-Beam Irradiated Xenotime-Type ErPO $_{4}$. J. Nucl. Mater. 2020, 539, 152265. https://doi.org/10.1016/j.jnucmat.2020.152265.

(33) Podor, R.; Cuney, M.; Nguyen, T. C. Experimental Study of the Solid Solution between Monazite(La) and $\left(\mathrm{Ca}_{0.5} \mathrm{U}_{0.5}\right) \mathrm{PO}_{4}$ at 780 Degrees $\mathrm{C}$ and $200 \mathrm{MPa}$. Am. Mineral. 1995, 80 (11-12), 1261-1268. https://doi.org/10.2138/am-1995-11-1215.

(34) Qin, D.; Mesbah, A.; Lautru, J.; Szenknect, S.; Dacheux, N.; Clavier, N. Reaction Sintering of Rhabdophane into Monazite-Cheralite $\mathrm{Nd}_{1-2 x} \mathrm{Th}_{\mathrm{x}} \mathrm{Ca}_{\mathrm{x}} \mathrm{PO}_{4}(\mathrm{x}=0-0.1)$ Ceramics. J. Eur. Ceram. Soc. 2020, 40 (3), 911-922. https://doi.org/10.1016/j.jeurceramsoc.2019.10.050.

(35) Förster, H.-J.; Harlov, D. E. Monazite-(Ce)-Huttonite Solid Solutions in Granulite-Facies Metabasites from the Ivrea-Verbano Zone, Italy. Mineral. Mag. 1999, 63 (4), 587-594. 
https://doi.org/10.1180/002646199548637.

(36) McCarthy, G. J.; White, W. B.; Pfoertsch, D. E. Synthesis of Nuclear Waste Monazites, Ideal Actinide Hosts for Geologic Disposal. Mater. Res. Bull. 1978, 13 (11), 1239-1245.

https://doi.org/10.1016/0025-5408(78)90215-5.

(37) Mesbah, A.; Clavier, N.; Lozano-Rodriguez, M. J.; Szenknect, S.; Dacheux, N. Incorporation of Thorium in the Zircon Structure Type through the $\mathrm{Th}_{1-\mathrm{x}} \mathrm{Er}_{\mathrm{x}}\left(\mathrm{SiO}_{4}\right)_{1-\mathrm{x}}\left(\mathrm{PO}_{4}\right)_{\mathrm{x}}$ Thorite-Xenotime Solid Solution. Inorg. Chem. 2016, 55 (21), 11273-11282. https://doi.org/10.1021/acs.inorgchem.6b01862.

Toby, B. H.; Von Dreele, R. B. GSAS-II : The Genesis of a Modern Open-Source All Purpose Crystallography Software Package. J. Appl. Crystallogr. 2013, 46 (2), 544-549.

https://doi.org/10.1107/S0021889813003531.

(39) Thompson, P.; Cox, D. E.; Hastings, J. B. Rietveld Refinement of Debye-Scherrer Synchrotron x-Ray Data from $\mathrm{Al}_{2} \mathrm{O}_{3}$. J. Appl. Crystallogr. 1987, 20 (2), 79-83.

https://doi.org/10.1107/S0021889887087090.

(40) Guo, X.; Lü, X.; White, J. T.; Benmore, C. J.; Nelson, A. T.; Roback, R. C.; Xu, H. Bulk Moduli and High Pressure Crystal Structure of $\mathrm{U}_{3} \mathrm{Si}_{2}$. J. Nucl. Mater. 2019, 523, 135-142.

https://doi.org/10.1016/j.jnucmat.2019.06.006.

(41) Strzelecki, A. C.; Kriegsman, K.; Estevenon, P.; Goncharov, V.; Bai, J.; Szenknect, S.; Mesbah, A.; Wu, D.; McCloy, J. S.; Dacheux, N.; Guo, X. High-Temperature Thermodynamics of Cerium Silicates, A-Ce $\mathrm{Si}_{2} \mathrm{O}_{7}$, and $\mathrm{Ce}_{4.67}\left(\mathrm{SiO}_{4}\right)_{3} \mathrm{O}$. ACS Earth Sp. Chem. 2020, 4 (11), 2129-2143. https://doi.org/10.1021/acsearthspacechem.0c00231.

(42) Neumeier, S.; Kegler, P.; Arinicheva, Y.; Shelyug, A.; Kowalski, P. M.; Schreinemachers, C.; Navrotsky, A.; Bosbach, D. Thermochemistry of $\mathrm{La}_{1-\mathrm{x}} \mathrm{Ln}_{\mathrm{x}} \mathrm{PO}_{4}$ Monazites $(\mathrm{Ln}=\mathrm{Gd}, \mathrm{Eu})$. J. Chem. Thermodyn. 2017, 105, 396-403. https://doi.org/10.1016/j.jct.2016.11.003.

(43) Zhang, L.; Shelyug, A.; Navrotsky, A. Thermochemistry of $\mathrm{UO}_{2}-\mathrm{ThO}_{2}$ and $\mathrm{UO}_{2}-\mathrm{ZrO}_{2}$ Fluorite Solid Solutions. J. Chem. Thermodyn. 2017, 114, 48-54. https://doi.org/10.1016/j.jct.2017.05.026.

(44) Strzelecki, A. C.; Bourgeois, C.; Kriegsman, K. W.; Estevenon, P.; Wei, N.; Szenknect, S.; Mesbah, A.; Wu, D.; Ewing, R. C.; Dacheux, N.; Guo, X. Thermodynamics of CeSiO 4 : Implications for Actinide Orthosilicates. Inorg. Chem. 2020, 59 (18), 13174-13183.

https://doi.org/10.1021/acs.inorgchem.0c01476.

(45) Strzelecki, A. C.; Barral, T.; Estevenon, P.; Mesbah, A.; Goncharov, V.; Baker, J.; Bai, J.; Clavier, N.; Szenknect, S.; Migdisov, A.; Xu, H.; Ewing, R. C.; Dacheux, N.; Guo, X. The Role of Water and Hydroxyl Groups in the Structures of Stetindite and Coffinite, $\mathrm{MSiO}_{4}(\mathrm{M}=\mathrm{Ce}, \mathrm{U})$. Inorg. Chem. 2021, 4. https://doi.org/10.1021/acs.inorgchem.0c02757.

(46) Estevenon, P.; Welcomme, E.; Szenknect, S.; Mesbah, A.; Moisy, P.; Poinssot, C.; Dacheux, N. Multiparametric Study of the Synthesis of $\mathrm{ThSiO}_{4}$ under Hydrothermal Conditions. Inorg. Chem. 2018, 57 (15), 9393-9402. https://doi.org/10.1021/acs.inorgchem.8b01390.

(47) Reynolds, H. S. Synthesis, Characterisation and Dissolution Studies of the Uranium Mineral Coffinite, Royal Melbourne Institute of Technology (RMIT) UNIVERSITY, 2013.

(48) Shuller-Nickles, L. C.; Ewing, R. C.; Becker, U. Atomistic Calculations of the Thermodynamic Properties of Mixing for Tetravalent Metal Dioxide Solid Solutions: (Zr, Th, Ce) $\mathrm{O}_{2}$. J. Solid State Chem. 2013, 197, 550-559. https://doi.org/10.1016/j.jssc.2012.08.033.

(49) Aizenshtein, M.; Shvareva, T. Y.; Navrotsky, A. Thermochemistry of Lanthana- and Yttria-Doped Thoria. J. Am. Ceram. Soc. 2010, 93 (12), 4142-4147. https://doi.org/10.1111/j.15512916.2010.04001.x.

(50) Subramani, T.; Navrotsky, A. Energetics of Formation and Disordering in Rare Earth Weberite $\mathrm{RE}_{3} \mathrm{TaO}_{7}$ Materials. Inorg. Chem. 2019, 58 (23), 16126-16133. https://doi.org/10.1021/acs.inorgchem.9b02675.

(51) Finkeldei, S.; Kegler, P.; Kowalski, P. M.; Schreinemachers, C.; Brandt, F.; Bukaemskiy, A. A.; Vinograd, V. L.; Beridze, G.; Shelyug, A.; Navrotsky, A.; Bosbach, D. Composition Dependent Order-Disorder Transition in $\mathrm{Nd}_{\mathrm{x}} \mathrm{Zr}_{1-\mathrm{x}} \mathrm{O}_{2-0.5 \mathrm{x}}$ Pyrochlores: A Combined Structural, Calorimetric and Ab Initio Modeling Study. Acta Mater. 2017, 125, 166-176. https://doi.org/10.1016/j.actamat.2016.11.059.

(52) Horlait, D.; Claparède, L.; Clavier, N.; Szenknect, S.; Dacheux, N.; Ravaux, J.; Podor, R. Stability and Structural Evolution of $\mathrm{Ce}^{\mathrm{IV}}{ }_{1-\mathrm{x}} \mathrm{Ln}^{\mathrm{III}} \mathrm{O}_{2-\mathrm{x} / 2}$ Solid Solutions: A Coupled $\mu$-Raman/XRD Approach Inorg. Chem. 2011, 50 (15), 7150-7161. https://doi.org/10.1021/ic200751m.

(53) Shin, D. W.; Bridges, C. A.; Huq, A.; Paranthaman, M. P.; Manthiram, A. Role of Cation Ordering and Surface Segregation in High-Voltage Spinel $\mathrm{LiMn}_{1.5} \mathrm{Ni}_{0.5-\mathrm{x}} \mathrm{M}_{\mathrm{x}} \mathrm{O}_{4}(\mathrm{M}=\mathrm{Cr}, \mathrm{Fe}$, and Ga) Cathodes 
for Lithium-Ion Batteries. Chem. Mater. 2012, 24 (19), 3720-3731.

https://doi.org/10.1021/cm301844w.

(54) Guo, X.; Szenknect, S.; Mesbah, A.; Clavier, N.; Poinssot, C.; Wu, D.; Xu, H.; Dacheux, N.; Ewing, R. C.; Navrotsky, A. Energetics of a Uranothorite $\left(\mathrm{Th}_{1-\mathrm{x}} \mathrm{U}_{\mathrm{x}} \mathrm{SiO}_{4}\right)$ Solid Solution. Chem. Mater. 2016, 28 (19), 7117-7124. https://doi.org/10.1021/acs.chemmater.6b03346.

(55) Ushakov, S. V.; Helean, K. B.; Navrotsky, A.; Boatner, L. A. Thermochemistry of Rare-Earth Orthophosphates. J. Mater. Res. 2001, 16 (9), 2623-2633. https://doi.org/10.1557/JMR.2001.0361.

(56) Mazeina, L.; Ushakov, S. V.; Navrotsky, A.; Boatner, L. A. Formation Enthalpy of $\mathrm{ThSiO}_{4}$ and Enthalpy of the Thorite $\rightarrow$ Huttonite Phase Transition. Geochim. Cosmochim. Acta 2005, 69 (19), 4675-4683. https://doi.org/10.1016/j.gca.2005.03.053.

(57) Risbud, A. S.; Helean, K. B.; Wilding, M. C.; Lu, P.; Navrotsky, A. Enthalpies of Formation of Lanthanide Oxyapatite Phases. J. Mater. Res. 2001, 16 (10), 2780-2783. https://doi.org/10.1557/JMR.2001.0381.

(58) Zhang, Y.; Navrotsky, A. Thermochemistry of Rare-Earth Aluminate and Aluminosilicate Glasses. $J$. Non. Cryst. Solids 2004, 341 (1-3), 141-151. https://doi.org/10.1016/j.jnoncrysol.2004.04.027.

(59) Popa, K.; Shvareva, T.; Mazeina, L.; Colineau, E.; Wastin, F.; Konings, R. J. M.; Navrotsky, A. Thermodynamic Properties of CaTh $\left(\mathrm{PO}_{4}\right)_{2}$ Synthetic Cheralite. Am. Mineral. 2008, 93 (8-9), 13561362. https://doi.org/10.2138/am.2008.2794.

(60) Robie, R.; Hemingway, B. S. Thermodynamic Properties of Minerals and Related Substances at $298.15 \mathrm{~K}$ and 1 Bar (10^5 Pascals) Pressure and at Higher Temperatures; 1995. https://doi.org/10.3133/b2131. 


\section{For Table of Contents Only}

\section{Synopsis}

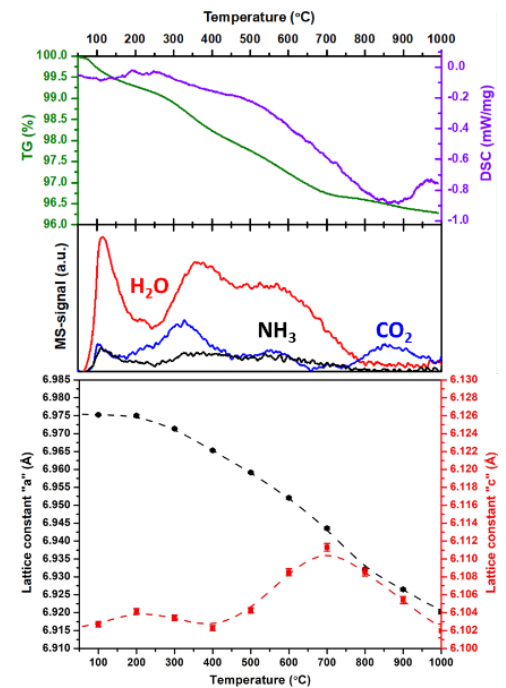

This paper is a complementary study to the one published in 2016 on thorium incorporation into zircon structure. It discusses effects of long-term storage and annealing on structure and thermodynamic properties of the mineral form doped with radioactive element. This is especially important in terms of the nuclear waste storage applications and understanding the durability of mineral structures in harsh environment of radioactivity. 